\title{
A bedside conversation with Wilder Penfield
}

$\mathrm{F}$ rom July 1, 1975 to June 30, 1976 , I served as an intern in internal medicine at the Royal Victoria Hospital in Montréal, Quebec after graduating from Emory University School of Medicine.

At that time, interns were still given their own on-call room. My pre-morning rounds ritual consisted of a maple donut and orange juice at the hospital coffee shop, while also devouring The Star, The Gazette and La Presse. Olympic fever was in the air. Separatist tensions were still palpable and René Lévesque, the charismatic, chain-smoking leader of the separatist Parti Québécois dominated the news.

I was fascinated by the renowned Montréal Neurological Institute, where I once went to watch neurosurgery through opera glasses from an enclosed observation area above the operating room.

Recently, I came across six prescription-size pages of handwritten notes from an hour-long conversation I had with the Institute's founder, Dr. Wilder Penfield on the morning of Apr. 3, 1976, when he was a patient in the Ross Pavillion at the Royal Vic. Having hoped to meet him since the start of my training, I stopped off at my room after completing night-call and signout to muster the courage to introduce myself and to pick up my copy of The Torch, his novel about Hippocrates' battle to lay the foundations of medicine.

On that sunny Saturday morning, Dr. Penfield, age 85, was alone in his room, looking wan and tired, but serene. When I tapped on the open door, he graciously invited me to sit by him at his bedside, adding, "I'm an interesting case, you know. Inflammatory myopathy, inclusion body myositis type. Have you read my chart? This damn myositis. Weakness. Can't do a thing. And on top, there's that cancer."

I told him I'd met a former patient of his, an attendant at the Veteran's Hospital who'd had viral encephalitis 30 years before and on whom he'd operated.

"Don't expect I did him much good," he quipped.

He beamed when I showed him my paperback copy of The Torch. "I had such fun writing it," he said. "It's the right way, really, the novelist approach. When you write imaginatively, you know what's right. The historian can't do that when he says such and such happened."

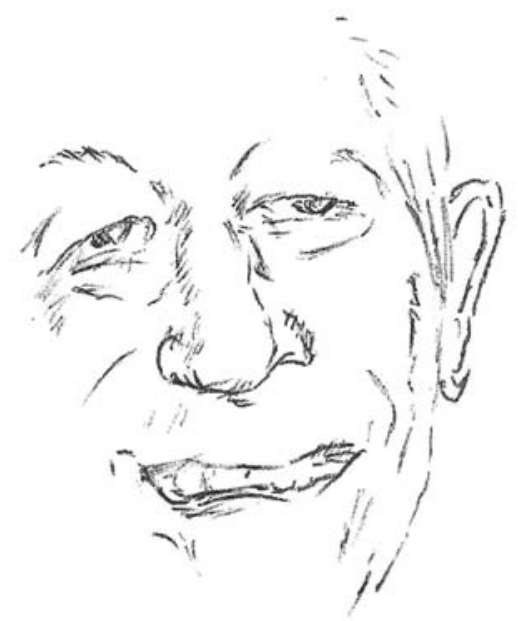

"When you write imaginatively, you know what's right," Wilder Penfield (above) told the author and artist, Alan Blum.

It was ironic that he should mention this, for here I am all these 35 years later, trying to reconstruct our conversation from a few notes that I have kept all these years and from my personal recollection. In this reimagined encounter, I glimpse what Dr. Penfield was asserting: even if the words aren't exact, the feeling the encounter engendered is accurate.

Dr. Penfield continued talking about his book. "When I was working on it at the Institute for Advanced Studies [at Princeton], one of [J. Robert] Oppenheimer's secretaries had to take over typing the manuscript. Well, Oppenheimer saw the thing and said, 'I've just seen the word "I" used on my typewriter.' He was a physicist, see, and dealing with the first person was something that hadn't happened to him."

In my notes, I quote Dr. Penfield as saying, "There's not much Hippocrates in Osler. At least not the individual. But it's all there." Although I can't recall the context, apart from alluding to The Torch, he venerated Sir William Osler, who made him a veritable member of his family when Penfield was a Rhodes Scholar at Oxford and Osler was Regius Professor of Medicine.

Another comment without context: "The killing of Socrates was sort of a strike." Perhaps this was a reference to the unrest in the hospital workplace. During my internship year, there were job actions by x-ray technicians, laboratory technologists, 14000 nurses, and 80000 nonprofessional employees. A cartoon by Girard in La Presse showed a surgeon at the doors of an operating room asking, "What would be the best time for a kidney transplant?" and a janitor replying, "I'll have to look at the strike schedule."

That morning, Dr. Penfield shared the story of how his career evolved when he returned to the US from England in 1921. "When I went to Henry Ford Hospital, they wanted to give me $\$ 5000$ to work there, and I went out and spoke to the hospital administrator, a man called Leopold - used to be Ford's secretary - I told him I was interested in the problem of decerebrate rigidity and wanted to do some work in the lab. But he said we've got a good man already in the lab, and if you've got a problem just tell him about it. So I said, 'I won't 


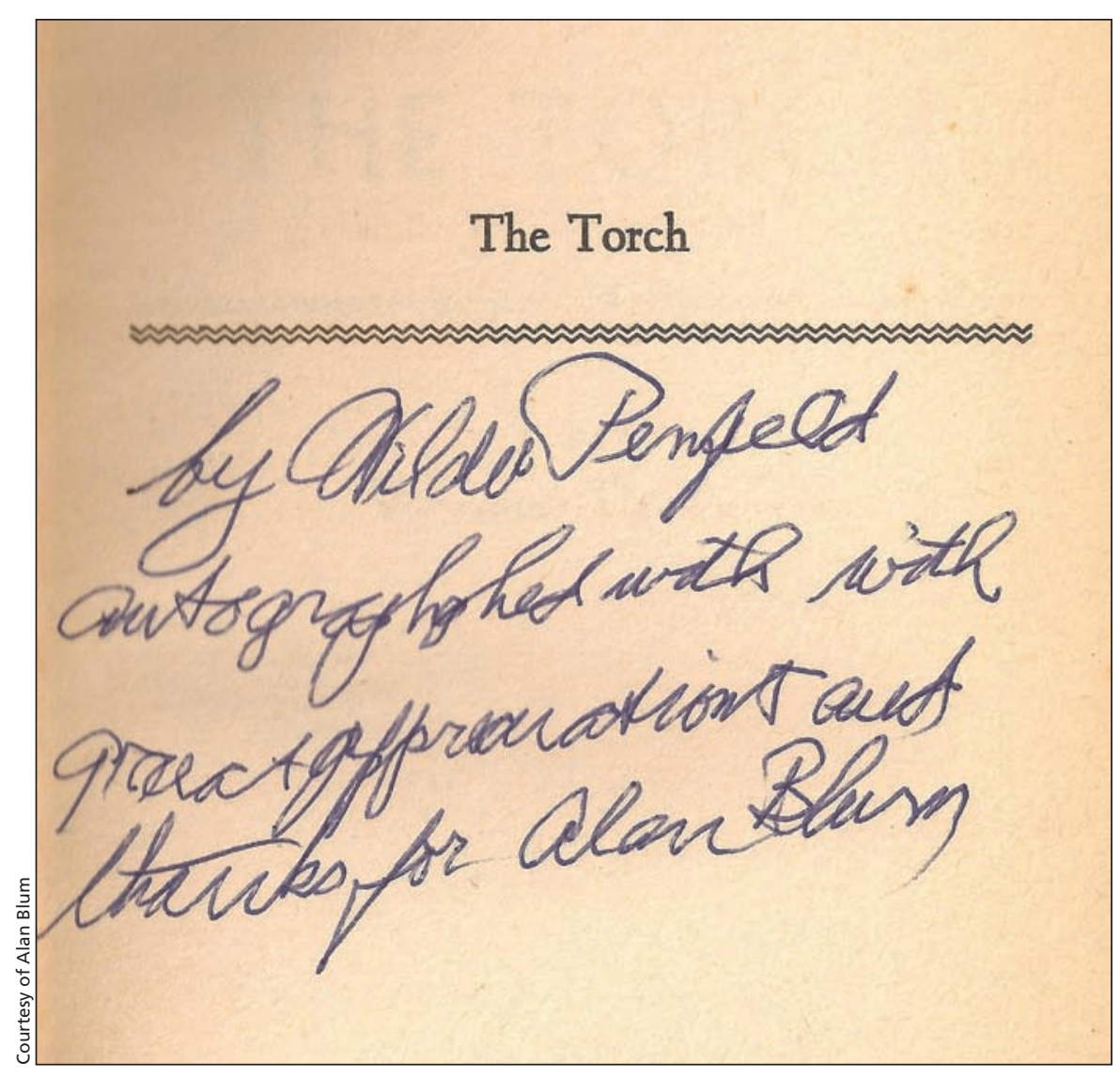

Blum went to visit Dr. Penfield that day to ask him to sign his copy of The Torch (above).

stay," and he thought I was playing that little game with him. So he said, 'I'll pay you $\$ 500$ more.'

"At the time I had two other offers of positions, at much lower salaries. I wrote my wife at Devil's Lake, Wisconsin, 'Would you be willing to go to Philadelphia or New York?' And the answer that came back was one word, 'Timbuktu.'

"Presbyterian in New York was changing to a fulltime hospital, and I met with the leader there. It looked perfect: three months in neurosurgery - I hadn't had much surgery - three months pathology, three months physiology, three months vacation. I had to tell him, honestly, that I'm not trained sufficiently in neurosurgery. 'But we want a neurophysiologist and a neuropathologist,' he said. So it all worked out brilliantly. Three years." While there he would be invited to bring together all the neurosciences under one roof for the first time in the world by founding the Montreal Neurological Institute.

I mentioned I'd read a review in The New York Times of his 1975 book, The Mystery of the Mind: A Critical Study of Consciousness and the Human Brain. He replied, "That review wasn't right: the remark that I made a belated admission of bilingualism. [He meant to say monotheism.]

"All it will take is someone finding how one form of matter is transformed into another. And, like Einstein said, it'll all be so simple. The brain's an electrical system. It runs with the same kind of electricity everything else does.

"It won't be long before they'll discover that switch that says when I'm asleep it's off, and in the morning when I wake up again it's on. Of course, when you're dreaming, that's half and half. And then the mind, where has it gone?

"I've been thinking about these things only lately, you know. It's hard to believe in predestination, and I've come to the conclusion that there's a plan and a God - that there's a bond between the Creator and the creative man. If you look at how the universe has evolved, it must be. Things come about when you least expect it."

"You believe in serendipity, then?" I asked.
"No, it's not that," he replied. "You're getting off track if you say that. If you set out to do your best and work hard, the paths will open up for you. I know. It's worked for me."

When I rose to leave, Dr. Penfield said, "Thank you, Alan. I didn't know there were such people."

Our conversation was cordial and wide-ranging. Most of the points he made were those he had obviously told to many other greenhorns before me. Several are included in his autobiography, No Man Alone: A Neurosurgeon's Life, which he'd completed only three weeks before our encounter.

On the Monday following my visit, a fellow intern whom I told of my encounter informed me that Wilder Penfield had just died. "You should have come up. We walked in the room and he died right then. He wasn't in pain. He didn't suffer. But you should have seen him. He died in a pensive pose."

I received a call that day from the director of the Montreal Neurological Institute, Dr. William Feindel, who had heard I'd visited Dr. Penfield and was curious to know what we'd talked about. A few hours after Dr. Penfield and I had met, I learned, he lapsed into unconsciousness. Dr. Feindel informed me that apparently I was the last person with whom he had spoken at length.

That week I attended the packed memorial service for Dr. Penfield at First Presbyterian Church. To my amazement, in the front pew sat my downstairs neighbour from our small apartment building on Sussex. We'd made small talk in the entranceway a few times, but I had not known that she was Dr. Penfield's granddaughter.

A couple of weeks later, Macleans published an interview with Dr. Penfield that it claimed was his last. But I knew better.

\section{Alan Blum MD}

Professor and Endowed Chair in Family

Medicine

The University of Alabama School of Medicine

Tuscaloosa, Ala.

Alan Blum would like to hear your recollections about Dr. Penfield: ablum@cchs.ua.edu

CMAJ 2011. DOI:10.1503/cmaj.110202 